УДК 340.12:061.1€С:304.4

DOI https:// doi.org/10.32837/yuv.v0i3.1953

\author{
В. Гайдамака, \\ аспірантка кафедри права Європейського Союзу \\ Національного юридичного університету імені Ярослава Мудрого
}

\title{
СОЦІАЛЬНЕ ПРАВО: ПРОБЛЕМИ ВИЗНАЧЕННЯ
}

Постановка проблеми. Натепер не існує єдиного підходу щодо визначення поняття «соціальне право». У своїх поглядах науковці розділилися на тих, хто розглядає це поняття з точки зору економіки, і тих, які схиляються до більш правового осмислення вказаного терміну. Окрім питань, пов'язаних із тлумаченням такої складної категорії як «соціальне право», ми стикаємося ще й із проблемою тлумачення та виокремлення його складників. У цій статті ми розглянемо такі складники соціального права як право соціального забезпечення та право на соціальну допомогу. Навколо «права соціального забезпечення» також ведуться жваві дискусіі. Чи можливо вважати соціальне забезпечення складником соціального захисту? Чи $є$ ці поняття тотожними?

Аналіз останніх досліджень і публікацій. Проблема визначення терміну «соціальне право» та його поділу на право соціального забезпечення та соціальної допомоги становить предмет зацікавлення для представників різних суспільних наук - як правознавців, так і економістів, соціологів, філософів. Серед науковців, які займалися розробкою цього питання, варто назвати Г. Гончарова, Н. Болотіна, Я. Лебедзевич, С. Прилипко, П. Рабінович, І. Яковюк та інших вітчизняних і зарубіжних правників.

Так, О. Мачульська вважає соціальне забезпечення складником соціального захисту [5]. О. Холостова робить висновок про те, що термін «соціальне забезпечення» був витіснений терміном «соціальний захист»
[7]. Існують й інші точки зору на співвідношення вказаних категорій, кожна 3 яких має право на існування.

Постановка завдання. Метою статті є дослідження такого феномену як соціальне право Європейського Союзу, визначення його структури і змісту, розмежування з близькими за змістом поняттями.

Виклад основного матеріалу. Соціальне право як самостійна галузь сформувалося в 1950-1960-х роках на основі комплексів норм права, що виокремлювалися із галузей трудового, фінансового, цивільного, адміністративного права [1, с. 90]. Цей процес був зумовлений потребами становлення й функціонування в країнах Заходу національних моделей соціальної держави (держав загального благоденства).

Соціальне право є тим феноменом, який існує в усіх країнах Європи i Північної Америки, що визначають себе як демократичні, соціальні і правові держави [4, с. 203]. При цьому подібно до соціальної держави соціальне право з моменту свого становлення викликає гострі дискусії з приводу своєї назви, структури, змісту і співвідношення 3 іншими галузями права.

Так, на думку І. Яковюка, соціальне право знаходить своє визначення через систему правових норм, в яких зафіксовані ключові положення соціальної політики держави та за допомогою яких здійснюється правове регулювання соціального захисту людей. При цьому предмет цієї галузі постійно розширюється і охоплюе 
питання, пов'язані з соціальним захистом; правове регулювання порядку формування і діяльності органів і установ соціального захисту (державних і недержавних), а також благодійних організацій; правове регулювання окремих моментів «промислових відносин» [2, с. 149-150, 154].

Досить влучно характеризує соціальне право Г. Гурвич, який визначив цю галузь як право інтеграціï, протилежне праву розмежувального розподілу і праву субординації чи панування («домініум» та «імперіум» римського права). Соціальне право засноване на довірі, взаємодопомозі і передбачає спільні зусилля, тоді як розподільне право і право розмежувальної координації засновані на недовірі та конфліктах, а право субординації - на підкоренні й віддаленні від права інтеграції через його відчуження і підкорення праву роз'єднання [3, с. 659].

M. Кобець визначає соціальне право через систему правових норм, за допомогою яких здійснюється правове регулювання соціального захисту людей $[2$, с. 154]. 3 цього визначення випливає, що соціальний захист $€$ неодмінним елементом соціального права.

Науковці не можуть дійти згоди в питанні стосовно того, чи є соціальне забезпечення складником соціального захисту або ж навпаки. Так, О. Мачульська, визначаючи соціальне забезпечення складником соціального захисту, вказує на те, що соціальний захист, окрім соціального забезпечення, включає ще й гарантії охорони праці, здоров'я і навколишнього природного середовища, мінімальної оплати праці та інші заходи, які є необхідними для нормальної життєдіяльності людини і функціонування держави [5, с. 47]. Т. Постовалова зазначає, що право соціального захисту забезпечує не тільки реалізацію заходів соціальної підтримки «слабких» соціальних груп, але й спрямоване на реалізацію заходів щодо соціального захисту всього населення [4, c. 203].

У соціальній енциклопедії поняття «соціального захисту» визначається як «захист від соціальних ризиків шляхом комплексного сприяння людині з боку держави у вирішенні різноманітних проблем протягом усього іï життя, починаючи з періоду виношування матір'ю дитини і завершуючи гідним похованням людини» [6, с. 345].

На думку О. Холостової, у країнах, які стали на шлях розвитку ринкової економіки, термін «соціальне забезпечення», який відбивав специфіку організації соціального захисту у централізовано-плановій системі господарювання, не може використовуватися для позначення ані всієі сукупності соціально-економічних відносин у сфері соціального захисту, ані ऑï адміністративних структур із новими функціями.

Термін «соціальне забезпечення» був витіснений із повсякденного вжитку терміном «соціальний захист». Останній означає систему пріоритетів і механізмів з реалізації законодавчо закріплених соціальних, правових і економічних гарантій громадян; органів управління всіх рівнів, інших інститутів, а також систему соціальних служб, покликаних забезпечити певний рівень соціальної захищеності, а також тих, які допомагають досягнути соціально прийнятного рівня життя населення відповідно до конкретних умов суспільного розвитку [7, с. 94, 195-196].

Соціальний захист у загально-соціальному плані можна інтерпретувати як створення суспільством умов, необхідних для нормального за конкретних історичних обставин існування й розвитку людини. Що означає «нормального»? Відповідь на це питання зумовлюється біологічною і соціальною обгрунтованістю потреб людини. Самі ж ці потреби, як результат історично-природного та соціального розвитку людини, 
не $€$ незмінними [8, с. 10]. Тобто, йдеться про потреби, які зазнають постійних змін із плином часу та розвитком суспільства і потребують ї задоволення за конкретних життєвих умов. Соціальний захист має бути гнучким і спрямованим на задоволення певних потреб конкретної людини відповідно до вимог сьогодення.

Соціальний захист населення став одним із неодмінних атрибутів соціальної політики будь-якої цивілізованої держави. Невід'ємною частиною соціальної держави є система соціального захисту населення, необхідна для реалізації матеріального благополуччя громадян, сприяння соціальній злагоді та солідарності в суспільстві.

Проблеми, пов'язані 3 регулюванням зайнятості, забезпеченням соціального захисту незахищених верств населення тощо завжди актуальні. Такі соціальні явища значно знижують рівень життя більшості населення країни, збільшують загрозу кризових явищ в економіці, перешкоджають створенню умов для стабілізації та економічного зростання.

«Соціальний захист населення» це поняття, яке має свою історію. Так, з кінця XVIII ст. в Європі та Росії починає формуватися державно-адміністративна система суспільної опіки (інституційне становлення системи допомоги, формування правової бази, адміністративного управління, що включає часткове фінансування державою соціальної допомоги). Особливістю цього етапу є те, що держава не прагне до прямого виконання соціальних функцій, а тільки сприяє у цьому іншим інститутам (інститути особистої і громадської благодійності, організації корпоративного соціального страхування, місцева влада, церква). Дві основні характеристики цього етапу (поява у держави власних соціальних функцій і спрямованість соціальної політики на всіх членів суспільства) взаємопов'язані і базуються на необхідності консолідації суспільства.
Перші елементи соціального захисту з'явилися у Німеччині вкінці XIX ст., коли держава почала виділяти кошти на різні соціальні програми. Розпочалася передача соціальних функцій від суспільства до держави. Термін «соціальний захист» був вперше використаний у Законі «Про соціальний захист США» в 1935 році, що законодавчо визначило новий етап для цієї країни, запровадивши інститут обов'язкового страхування щодо старості, смерті, інвалідності та безробіття. Незабаром цей термін почав широко використовуватися у багатьох країнах світу, розкриваючи сутність проблеми з організації національних систем допомоги непрацездатним громадянам, а також громадянам похилого віку.

Зміст соціального захисту розкривається через такі ознаки:

- це система суспільних відносин, покликана сприяти задоволенню особистих матеріальних потреб громадян через індивідуальну форму розподілу зі спеціальних фондів;

- соціальний захист здійснюється державою за рахунок коштів суспільства;

- кошти надаються замість заробітної плати або як додаток до неї у випадках, передбачених законодавством (при втраті або зниженні заробітку, при неможливості працевлаштування) [9, с. 6].

Соціальний захист повинен бути безперервним, охоплювати всі сфери життя людини і надавати людині можливість нормального життя (навіть за обставин настання соціальних ризиків). Соціальний захист повинен бути гнучким, доступним і здатним вирівнювати соціальні умови життя для усіх верств населення. Тобто, соціальний захист повинен допомагати в подоланні стратифікації як у фізичних, так і в соціальних можливостях «слабких груп» і забезпечених верств суспільства. Кожна людина повинна мати можливість отримання освіти, кваліфікації та роботи. 
Необхідно зазначити, що серед вчених відсутній єдиний підхід щодо тлумачення поняття «соціальний захист». Так, В. Грушко та Е. Лібанова вважають, що соціальний захист населення - це матеріальне забезпечення усіх без винятку громадян не нижче соціальних нормативів і забезпечення їм гідних умов життя. Таким чином, соціальний захист передбачає певний рівень матеріальної забезпеченості (підтримка рівня доходів, захист добробуту). В Україні - це система відносин між державою, господарськими структурами та громадянами, в процесі яких за рахунок частини валового внутрішнього продукту утворюються i використовуються фонди фінансових ресурсів для матеріального забезпечення та обслуговування окремих категорій і груп громадян. 3 позицій економіки соціальний захист $є$ правилами перерозподілу суспільного багатства на користь людей, які тимчасово або постійно потребують особливої підтримки з боку суспільства [10, с. 48-49, 53].

Влучним є визначення соціального захисту, наведене в Американській енциклопедії: «Соціальний захист у загальному розумінні цього поняття означає безпеку та свободу від страху, спрямовані на суспільство як на групи взаємопов'язаних і залежних один від одного людей» [11, с. 78]. У Всесвітній енциклопедії наведені економічні аспекти такого поняття: «Соціальний захист - це урядова програма, яка допомагає працівникам, пенсіонерам та їхнім сім'ям досягти рівня економічного забезпечення» [12, с. 89].

Принципово відмінну від наведених вище точку зору відстоюють вітчизняні правознавці Г. Гончарова, В. Жернаков, С. Прилипко. Вони вважають, що намагання розмежувати за значенням терміни «соціальне забезпечення» $\mathrm{i}$ «соціальний захист» $€$ невиправданими, оскільки виявити серйозні відмінності у змісті названих категорій ще нікому не вдавалося. I соціальне забезпечення, i соціаль- ний захист спрямовані на матеріальне забезпечення непрацездатних громадян у разі втрати ними заробітку з різних причин та в інших випадках, передбачених законодавством України про соціальний захист. Виходячи зі ст. 46 Конституції України, ці терміни слід вважати синонімами [13, с. 138-139].

Досить влучними є висновки Н.Б. Болотіної щодо цієї дискусії. По-перше, вона вважає, що за межами соціального забезпечення, але в рамках соціального захисту перебувають відносини, які регулюються іншими галузями права, зокрема трудовим, екологічним, адміністративним, фінансовим тощо. По-друге, поняттям соціального захисту охоплюються, крім права на соціальне забезпечення, й інші соціальні права, зокрема, право громадян, які потребують соціального захисту, на отримання житла безоплатно або за доступну для них плату (ч. 2 ст. 47 Конституції Україн), право на охорону здоров'я (ст. 49), право на безпечне для життя і здоров'я довкілля (ст. 50), право на освіту (ст. 53) [14, с. 37]. Ми поділяємо ці зауваження.

Недоречно говорити про соціальні права людини лише в контексті трудового права. Соціальний захист $€$ тим універсальним елементом, який стосується й інших напрямів соціальної діяльності держави. Соціальним забезпеченням охоплюються такі соціальні ризики: хвороба, материнство, старість, інвалідність, професійні захворювання та нещасні випадки на виробництві, безробіття, сімейні виплати незалежно від того, фінансуються вони із бюджету або страхових внесків і управляються приватними або публічно-правовими установами [4, с. 203].

Соціальне забезпечення є тим феноменом, за допомогою якого людині дається змога досягти гідного рівня життя, задовольнити свої як матеріальні, так і нематеріальні потреби. Це унікальний вид захисту прав людини, 
покликаний забезпечити ї основні потреби, серед яких охорона здоров'я, оскільки саме людина вважається найвищою соціальною цінністю, a іï життя є безцінним.

Висновки. Підбиваючи підсумки, необхідно зазначити, що розвинуте, досконале за своїм змістом соціальне право $є$ неодмінною передумовою забезпечення соціально-економічних прав людини в демократичній, соціальній правовій державі. Забезпечення гідного та достатнього життєвого рівня кожній людині повинно бути основним завданням будь-якої цивілізованої держави.

Соціальний захист належним чином може бути забезпечений лише в соціальній правовій державі. «Соціальність» держави є важливою передумовою забезпечення соціальної захищеності громадян з боку держави в умовах розвитку ринкової економіки, що здійснюється за допомогою соціального права. Тому не можливо говорити про «соціальне право» окремо від «соціальної держави».

Однією 3 функцій соціального права є те, що воно забезпечує гідний рівень життя усім громадянам держави, а забезпечується це лише шляхом реалізації ідеї загального добробуту. Крім цього, соціальне право у правовому сенсі означає задоволення потреб і розвиток здібностей кожної людини за умови, що цей вільний розвиток індивіда гармонійно поєднується зі свободою усіх інших i особистою відповідальністю, що також вказує на соціальну державу.

Отже, соціальним правом слід вважати галузь права, яка складається з юридичних норм, покликаних забезпечити соціальний захист індивіда, який вступає у соціальні відносини iз навколишнім світом. Соціальне право як галузь права складається із права соціального забезпечення (або ж соціального захисту) та соціальної допомоги. Намагання розділити поняття «соціальне забезпечення» та «соціальний захист» $€$ невиправда- ними, тому що виявити суттєві відмінності у змісті цих категорій проблематично.

Актуальність досліоження феномену соціального права є беззаперечною, оскільки від розвиненості і досконалості иієї комплексної галузі права безпосередньо залежить ефективність функиіонування сучасної демократичної, сочіальної правової держави, солідарність i стабільність суспільства, ступінь гарантованості соціально-економічних прав людини.

Ступінь ичивілізованості сучасних держав оцінюеться з позиціi оцінки ступеня розвиненості $і$ юридичної досконалості соціального права. Автор обтрунтовує зв'язок соціального права як елемента системи права з соціальними правами, які належать до другого покоління прав людини $i$ характеризуються тим, що для їх реалізації потрібні позитивні діі контрагентів-носіїв изих прав, зокрема держави.

3 огляду на різноманіття наукових позицій стосовно розуміння соціального права у статmі авторка робить спробу систематизувати погляди сучасних вітчизнянuх юристів 3 иього питання $i$ визначити співвідношення понять «соціальне право», «соціальний захист» $i$ «право соціального забезпечення» та іх взаємовплив; намагається визначити коло відносин, які складають предмет правового регулювання соціального права. У cmammi з позиції системної методологіï аналізується місце соціального права в системі національного права. Авторка зазначає, що дискусї щодо визнання соціального права самостійною галуззю насамперед пов'язані з унікальністю предмета правого регулювання.

Відокремлення комплексів норм трудового, ичивільного, фінансового таадміністративногоправавсистему соціального права переслідуе 
очевидну мету - забезпечити системність функціонування правового механізму реалізаціі соціальних прав людини $i$ громадянина, закріплених на конституційному рівні, оскільки ефективна реалізації соціальних прав здебільшого залежить від досконалості їх конкретизаціі на рівні нормативноправових актів.

Ключові слова: соціальне право, соціальна держава, соціальний захист, соціальне забезпечення.

\section{Gaydamaka V. Social law: problems of defining}

The relevance of the study of the phenomenon of social law is undeniable, since the development and perfection of this comprehensive branch of law directly affect the effective functioning of a modern democratic and social state based on the rule of law, solidarity and stability of society, the degree of guarantee of social and economic human rights.

The degree of civilisation of modern states is assessed from the standpoint of the degree of development and legal perfection of social law. The author argues that social law, as an element of the legal system, is linked to social rights, which belong to the second generation of human rights and are characterized by the fact that their realization requires positive action by the parties to the rights holders, in particular the state.

Taking into account the diversity of scientific positions on the understanding of social law, in the article the author attempts to systematize the views of modern domestic lawyers on this issue and to determine the relationship between the concepts of "social law", "social protection" and "social security law" and their mutual influence; an attempt is made to determine the range of relations which constitute the subject of legal regulation of social law. The article analyses the place of social law in the system of national law from the standpoint of a systematic methodology. The author notes that the discussion on the recognition of a social law as an independent branch is primarily related to the uniqueness of the subject of legal regulation.

The separation of complex norms of labor, civil, financial and administrative law into the system of social law pursues the obvious goal - to ensure the systematic functioning of the legal mechanism for the realization of social rights of human beings and citizens enshrined at the constitutional level, since the effective realization of social rights largely depends on the perfection of their concretization at the level of normative legal acts.

Key words: social law, welfare state, social protection, social security.

\section{Література}

1. Панкевич О.3. Соціальна держава та права людини «другого покоління» (загальнотеоретичне дослідження). Праці Львівської лабораторії прав людини i громадянина Науково-дослідного інституту державного будівництва та місиевого самоврядування Академії правових наук України. Серія 1. Дослідження та реферати. Випуск 11. Львів : "Астрон», 2006. $176 \mathrm{c}$.

2. Яковюк I.В. Соціальна держава: питання теорії $i$ иляхи ї становлення: Әис. канд. юрид. наук: 12.00. Харків. 2000. $199 \mathrm{c}$

3. Гурвич Г. Декларация социальных прав. Антология мировой правовой мысли. В 5 m. М. : Mыслль, 1999. T. 3.: Eвpona. Америка: XVII - XX вв. C. 657-661.

4. Постовалова Т.А. Координация и гармонизачия сочиального права Европейского Союза. Проблемь развития юридической науки и совершенствования правоприменительной практики. Минск: БГУ, 2005. С. 203-212.

5. Мачульская Е.Е. Право социиального обеспечения : учебное пособие для ВУЗов. 2-е изд. М. : Книжньй мир, 1999. 240 с.

6. Социальная энциклопедия / Редкол.: А.П. Горкин, Г.Н. Карелова, Е.Д. Катульский и др. М. : Большая Российская Энщиклопедuя, 2000. $438 \mathrm{c}$. 
7. Холостова Е.И. Социальная политика: учебное пособие. М. : ИНФРА-М, 2001. 204 c.

8. Рабінович П.м. Права людини: концептуальні засади. Права людини $i$ громадянина: проблеми реалізації в Україні : праці Львівської лабораторіі прав людини. Академіі правових наук України / Редкол. П.М. Рабінович (голов. ред.) та ін. К. : Iн Юре, 1998. C. 9-19.

9. Ярошенко И.С. Право социиального обеспечения : учебное пособие. Киев : КНЭУ. 2005. 232 с.

10. Лебедзевич Я.В. Система социальной защиты: эволюиия и взаимосвязь категорий. Финансы и кредит. 2014. № 23(599). C. 48-55.

11. The Encyclopedia Americana. Complete in thirty volumes. Vol. 25. NewYork. 1973. P. 102.

12. The World Book Encyclopaedia: Complete in 22 vol. - vol. 18. Chicago; London; Sydney; Toronto. 1994. P. 320.

13. Гончарова Г., Жернаков В., Прилипко С. Підручник з пенсійного забезпечення є, але чи є пенсійне право? Право України. 1998. № 12. С. 138-140.

14. Болотіна Н. Право людини на соціальне забезпечення в Україні: проблема термінів і понять. Право України. 2000. № 4. C. 35-39. 